\title{
DRIVERS AND INHIBITORS OF DIVERSITY AND SOCIAL JUSTICE IN THE SOUTH AFRICAN HIGHER EDUCATION SECTOR: REFLECTIONS ON A DECOLONISED CURRICULUM
}

\author{
M. J. Themane \\ Department of Education Studies \\ University of Limpopo \\ Polokwane, South Africa \\ e-mail: themane.mahlapahlapana@gmail.com / https://orcid.org/0000-0002-2097-8538
}

\section{ABSTRACT}

This article analyses factors that drive or inhibit students' epistemic access to higher education in South Africa. The analysis is in response to a need for institutional diversity and programme differentiation in our higher education institutions. The article intends to contribute to the ongoing debates on decolonisation and the social justice agenda in South African higher education. I argue that the first point of departure should be a focus on curriculum change. To this end I raise three arguments: firstly, the agenda on the size and shape of the system is not based on the pursuit for social justice and decolonisation, but on flippant political pursuits and markets. Secondly, the principles that govern the selection, organisation and sequencing of curriculum are not based on post-structuralism, but rather on structuralism. Thirdly, historically disadvantaged students do not have epistemic access and success in higher education.

Keywords: curriculum change, decolonisation, epistemic access, higher education, politics, markets

\section{INTRODUCTION}

Changing university curricula is like moving a grave yard. It is an arduous task. This is ironic given the fact that universities are supposed to be places of free and critical thinking that leads societal change (Swartz et al. 2019). They are supposed to be citadels of new knowledge because they house a community of teachers and scholars. They are supposed to be non-sectoral and democratic in nature. But, regrettably, this seems not to be the case (Johnson 2020). I raise this assertion because I argue that current deliberations that shape curricular changes in the South African higher education landscape appear to be following a different agenda from that of the National Plan for Higher Education (NPHE) (Department of Higher Education and Training (DHET) 2001). The Plan seeks to ensure diversity through the type and range of qualifications offered to transform higher education. Deliberations that shape curricular debates in South African universities have steered away from their missions. To explain this assertion, 
I am guided by the question: What drives curricular deliberations at South African universities today?

\section{DRIVERS OF CURRICULAR DELIBERATIONS AT SOUTH AFRICAN UNIVERSITIES}

The question of what should drive curricular deliberations at universities is moribund. But, is it necessary to engage in such a debate? Indeed, it is a pertinent question if we are to decolonise higher education curricula in South Africa. For example, decolonising the university curriculum needs a shift from decolonisation to decoloniality. Ndlovu-Gatsheni's (2015) distinguishes decoloniality from decolonisation. She contends that decoloniality is not only a political and epistemological movement aimed at the liberation of (ex-)colonised people, but also a way of thinking, knowing and doing things. If this conceptualisation is to be upheld, universities then need to base their deliberations on rationality rather than on flippant political and market forces. Indeed, several researchers have entered this fray from different perspectives. Keet (2014) has blamed the lack of progress on the decolonisation project on the conditions of knowledge reformulations and their expressions as disciplines. On the other hand, Mbembe (2016) blames its slow progress in structures; access; large systems of authoritative control; assessment procedures and methods of evaluation and curricula changes that dominate curriculum reform at universities. Chilisa (2017) has argued for the adoption of indigenous research methods to transform curricula. Mashiyi, Meda, and Swart $(2020,146)$ purport that "decolonisation is a complex and multi-layered concept, therefore hard to realise". These divergent views underscore why it is important to raise the level of debates on colonisation to a theoretical level, which I am afraid, is not the case.

These authors seem to have struck the right note about what should constitute the decolonisation agenda. However, I argue that the size and shape of higher education mission seem not to be in tandem with what these authors are raising. This observation is based on two examples. Firstly, transformation of technikons into Universities of Technology (UoT) has contributed to what Essop (2020) calls mission and academic drift. In this case, technikons which were renowned for good industry experience (the mainstay of their training) is now devalued in favour of academic pursuits. This can be seen in the recruitment of their staff. More emphasis is now put on academic qualifications against industry experience. Additionally, there has been a shift from diploma to degrees. There has been a steady increase in the offering of undergraduate degree programmes and post-graduate qualifications. For example, between 2005 and 2017 the proportion of headcount enrolments in diploma programmes in the UoTs declined from 80.5 per cent to 70.1 per cent (Essop 2020). 
Secondly, in recent years, there has been skewed formula for funding disciplines, where science, technology, engineering and mathematics (STEM) disciplines have received a lion's share of the budget compared to their social and humanities counterparts. While understanding that STEM subjects play a significant and directly causal role to economic productivity and innovation, it is regrettable that this skewed focus has come at a cost for the humanities (Blackie, Le Roux and McKenna 2016).

Undoubtedly, higher education should contribute to the development of the economy, however such a contribution should not be at the expense of the pursuit of knowledge. On this, Kraak (2000, iii) is instructive when he says:

"the university is shifting away from its traditional liberal formulation as a house of knowledge detached from the larger society to pursue science unhindered by the narrow interests of government and business, where intellectual labour has become commercialised serving primarily the innovation demands of the new global knowledge economy."

Universities need to strike a good balance between the need for economic development and education. This can be achieved by diversifying the higher education system. Such an approach will be in line with The White Paper for Post-School Education and Training, which seeks to promote the improvement of quality and building appropriate diversity. The aim is to ensure that a wide range of high quality options is provided throughout the system (DHET 2014, xiii).

The balance between economic development and the pursuit for knowledge should form the cornerstone of decolonisation. At present, there appears to be a drifting away from the latter in favour of economic development, which threatens the decolonisation project. In this observation I am not alone. Saltmarsh and Hartley (2011) in their paper "To serve a larger purpose: Engagement for democracy and the transformation of higher education" call for a reconsideration of the purpose and practice of engaged scholarship and teaching. Specifically, they call for the role of higher education's civic engagement efforts in the creation of a deliberative, participatory democracy, which I think is what is missing in the South African higher education debate on decolonisation. This call awakens us to the need for a shift in orientation from "civic engagement" to "democratic engagement". For such a shift to happen there is a need to restructure traditional cultures and organising structures embedded in the European and North American thought of the role of a university.

Thus, while higher education is important to national economies, both as an industry, in its own right, and as a source of trained and educated personnel for the rest of the economy, I argue as others (Throw 2007) do that such a focus should not override its primary role of the promotion of social justice and development of a democratic society. In South Africa, social 
justice and transformation seem to have been put on the back burner. Singh (2011) argues in the same vein when she argues that issues of social justice higher education have been appropriated into some neo-liberal strategies for growing competitive economies. However, it is doubtful whether it is possible to advance the purposes of social justice in higher education in such an environment (Bhambra et al. 2018).

It is imperative that this vision be placed back on the agenda (Singh 2001). Such an effort appears to be a tall order (Badat 2010). Unless deliberate efforts are made to place social justice and transformation on the centre stage, the dream of a decolonised and inclusive curriculum will remain a pipedream. Perhaps, the recent call by students for a decolonised curriculum is a blessing in disguise. I think that universities have been awakened to rethink their role and that social justice issues have come back to the agenda. However, I am pessimistic that such deliberations will be knowledge-based as Jansen (2017) rightfully alludes that there is a knowledge at South African universities. This leads to my second argument namely that the principles that govern the selection, organisation and sequencing of curriculum are not based on post-structuralism, but rather on structuralism. This claim I endeavour to proof in the next section

\section{PRINCIPLES FOR CONTENT SELECTION, ORGANISATION AND SEQUENCING}

In this section I want to address my second argument, namely that the principles that govern content selection, organisation and sequencing at South African universities seem to be based on colonised theories (structure-oriented theories rather than value-oriented ones). Most of the contested issues on the decolonisation of universities revolve around curriculum change. To put this in perspective, we need to sketch out a background to this consciousness. Student movements campaigns to challenge Eurocentric domination and lack of diversity in curricula in universities gave birth to a decolonised curriculum. These campaigns were built on earlier movements organised on notions of social justice and addressing inequalities (Bhambra et al. 2018). But as to what exactly decolonisation mean remain elusive because its multiplicity of meaning which involves diverse definitions, interpretations, aims and strategies (Begum and Rima 2019). However, if we were to adopt the interpretation advanced by Bhambra et al. (2018, 9), we can divide the definitions of the term into two strands, namely, as a way of thinking about the world, which takes colonialism, empire and racism as their empirical and discursive objects of study. And two, as an offer to alternative ways of thinking about the world and alternative forms of political praxis.

Given this conceptualisation, issues of content, pedagogy and assessment come to the fore in the decolonisation of the university. Despite its importance, students and academics are clear 
on the problem of implementation (Jansen 2017). The practical implications of what should be done remain obscure. I agree with Jansen (2017) that transform the curriculum requires a political will. The current approaches to curriculum reform at universities seem to lack the will or courage to dismantle Eurocentric colonial structures entrenched in the system. I suggest that to achieve this. I want to demonstrate this on two grounds. One, I wish to show the importance of flexibility in the selection, organisation and sequencing of the curriculum in pursuit of a decolonised and diverse curriculum. Two, I want to show that although the structure-oriented curriculum theories might be good, they are limited, and therefore unable to decolonise the curriculum

As a precursor to the two points, a quick reminder of what curriculum is, might be necessary. The concept curriculum has for long eluded both scholars and practitioners (Young 2014). The lack of a definite conceptualisation of the term makes it difficult for scholars to describe what a transformed or a decolonised curriculum looks like. This lack of clarity leads to its different conceptualisations, which in turn influence how it is theorised and practised (Wyse et al. 2014).

There are basically two broad views of curriculum. The narrow view and the broad view. The narrow view sees curriculum as a document such as a syllabus, or a list of subjects/courses to be covered for a specific programme. In contrast, the broad view of curriculum views curriculum as more than just a list of subjects or content to be studied, but as encompassing how such content is selected, organised and sequenced.

The narrow view is referred to by Hoadley, and Jansen $(1999,37)$ as curriculum-as-plan and the broad view as curriculum-in-practice. Authors (Bernstein 1971; Jansen 1999; Muller 2006) use terms such as the intended curriculum, the prescribed curriculum, the official curriculum, the formal curriculum, the curriculum as blue print, etc. for curriculum-as-plan; and they refer to curriculum-in-practice as the enacted curriculum, the practised curriculum, the actual curriculum, the lived curriculum, the curriculum as experienced.

The two views have led to the development of two conceptualisations, and in turn to the development of a number of models. The two main ones are: the objectives model and the process model. The objectives model emphasises the development of a curriculum that is based on objectives to be achieved. The purpose of these objectives is to guide what content is to be selected and how it should be taught. The objectives should specify the expected learning outcomes in terms of specific measurable behaviours.

Conversely, the process model of curriculum design comes from the curriculum-inpractice view. It focuses on how things happen in the teaching learning situation, and is more open-ended than the objectives model. Curriculum design focusing on the process model 
emphasises how students are learning, what their thinking is, and how it will impact future learning. I subscribe to this model because I think it has the possibility to deliver a decolonised curriculum. The fact that it open-ended allows students and lecturers to adjust and align it as they see it fit. For here lecturers can as Darling-Hammond et al. $(2020,97)$ suggest, use

"well-vetted strategies that support the kinds of relationships and learning opportunities needed to promote children's well-being, healthy development, and transferable learning. These strategies could help, educators to respond to individual variability, address adversity, and support resilience, such that schools can enable all children to find positive pathways to adulthood."

This is echoed by Osher et al. (2020b). Strong community relationships with parents, siblings, peers, caregivers, and childhood settings, schools, classrooms, and school-based interventions are important for learning and development (Osher et al. 2020b, 6).

Deleuze and Guattari (1984) speak of curriculum as always becoming and as a rhizome. By rhizome they suggest that things in the world are always interconnected although such interconnections are not always as the rhizome roots are. By becoming, they explain that the process of "becoming" is not one of imitation or analogy; it is generative of a new way of being that is a function of influences rather than resemblances. The process is one of removing the element from its original functions and bringing about new ones. These constructs, and other related ones, look suitable for thinking about curriculum as a process rather than a product. South African higher education could benefit by using these constructs for envisioning a dynamic and vibrant curriculum that addresses the needs of students. Understanding it in this way has implications about how we can theorise about and practice with a decolonised curriculum.

Returning to my thesis, I think that content selection, organisation and sequencing of curriculum hinge on our conception of what curriculum is. Those who subscribe to curriculumas-plan or document follow the objective models of curriculum design.

This way of selecting content, organising and sequencing is good but limited, and does not deliver a decolonised curriculum because of its lack of resouces, both physical and theoretical. Morrow (2009) calls these epistemic goods. Muller (2009) distinguishes between two forms of access: formal access (institutional access) and epistemological access (access to goods distributed by the institution). The latter is important when considering the selection of content; its organization and sequencing. For example, funding for students who come from disadvantaged backgrounds is essential for their success; as they need to buy food, books and so forth. Osher et al. (2020a) in their book entitled: Thriving, robust equity, and transformative learning and development: A more powerful conceptualization of the contributors to youth 
success, call to obviate the cumulative impacts of inequity and trauma, that plague students from disadvantaged backgrounds when they point to the need to improve opportunity structures to address and eliminate the disadvantages created by current systems and practices. They call for the elimination of the root causes of structural inequality in opportunities for youth to thrive across all domains.

Without belabouring the point any further, I want to conclude this section by further supporting my thesis for basing the selection, organisation and sequencing of curriculum on the conception of what Cornbleth (1997) calls curriculum as contextualised social process and the work of Bernstein (1971) called the Pedagogic Discourse. Cornbleth (1997) regards the selection, organisation and sequencing of curriculum as always context-bound and always responsive to the needs of students. This could be understood as follows. In this era of the Covid-19 pandemic, universities are expected to resort to online teaching. This has not been an easy ride for particularly historically disadvantaged students, who experience problems with internet connectivity and lack of data. These and other related challenges are inhibitors to levelling the plain fields and giving epistemic access and success to historically disadvantaged students.

Bernstein's (1971) theory attempts to connect a macro level class of power in relation to the micro level educational process of the school. He further argues that for an education policy or curriculum to develop into "new knowledge" there should be engagement and interaction of stakeholders at the macro and micro levels. Failing to do so could result in failure of the implementation programme.

If the decolonisation project is to take root in South Africa, policy developers at the upper structures or at the macro level of government (which is the department of higher education in this case) need to keep in touch with the micro level, which includes higher education institutions. Thus, Cornbleth (1997) regards the context of an individual institution as the epicentre of curriculum design and implementation. The theory stresses the importance of consultation and advocates a symbiotic relationship between the macro and the micro levels if an initiative such as the decolonisation project is to succeed. For example, there is a need for consultation of all stakeholders, including students and civil society. In my view this intersectionality is not happening between universities and the Department of Higher Education and Training.

I am of the view that education policy frameworks are good, but not good enough to transform the higher education landscape in South Africa. There is more needed than just grand policies. In some cases, policies do not consider the context of an institution. Such policies because they are top-down in approach, they are unlikely to succeed. Policies need to be inside- 
driven or bottom up. To borrow from Deleuze and Guattari's words (1984), higher education in South Africa has been "deterritorialised". Deterritorialisation is the separation of social, cultural and political practices (such as people, objects, languages, or traditions) from a location. Western curriculum theories have been transplanted from the countries of their region and planted in Africa, and other colonised countries. A good example is the language of teaching, which has been extensively documented elsewhere (Makalela 2015). African problems need African solutions.

These solutions can include, a reflection on the social capital (cultural and social) that students from historical disadvantaged backgrounds bring along to the university. For example, if the content to be taught is delivered in a foreign language (such as English or Afrikaans), how can the curriculum be mitigated. This way of thinking defies what most academic staff are comfortable with. For instance, relying on notes that they were given by the professors when doing their first of year study that have no connection with the student's context or background.

Academics tend to start a cycle, rising up by inventing new ideas and principles and reaching their zenith where these flourish. But, in the course of time, these ideas and principles tend to become irrelevant as they fail to solve the contemporary problems and face new challenges (Themane 2011; Luckett 2009). When the once-trusted and relied upon solutions that are provided by these principles and ideas become obsolete when a crisis strikes. Curriculum change should always be in state of flux. A curriculum should be, in the words of Deleuze and Guattari (1984) a nomad or what they term a rhizome.

\section{EPISTEMIC ACCESS AND SUCCESS}

This section offers a critical analysis of the concept epistemological access and success as part of the project to decolonise, diversify and differentiate curriculum development in South African higher education. One of the irreparable damages caused by colonialism in Africa has been the denial of higher education to the majority its young people. Therefore, decolonisation has, as one of its dimensions, the opening of access. This is premised on the fact that exclusion from higher education was a political tool to keep the majority of South African youth from disadvantaged communities out the economy.

So, from the onset the White Paper 3 (DoE 1997) was clear on its mandate, namely to transform higher education in South Africa. One of the offshoot policies, the Policy Framework on differentiation in the South African Post-School system (DHET 2014, 3) indicates that historically, apartheid higher education was differentiated and diversified along lines of ethnicity and geographical location and language. At the core of this system was the curriculum, in its broad definition. Thus, epistemic access and success is sine qua non for a decolonised 
curriculum. This section therefore examines this important aspect of the transformation. Firstly, I will explore its conceptualisation, and secondly how it can be improved in pursuit of a diversified and differentiated system.

Different meanings for epistemic access and success exist. Broadly, these meanings can be grouped into two categories. Those that see access as merely the physical entry into an institution of higher learning, and others being those that go beyond physical access to include the support that goes with it. This view is well captured by Cross and Atinde (2015) when he reflects that it is well documented that students who are educationally and economically disadvantaged are less likely to enrol in postsecondary education, and if they do enrol, they are less likely to receive a degree.

Some scholars (Cross and Atinde 2015; Badat 2014; Du Plooy and Zilindile 2014) explain epistemic access and success as a process that involves both the integration into university life and success or completion of the programme. I subscribe to the latter view, which sees access as a process that goes beyond mere physical access, namely, a process that involves integration into university life and successful completion. This calls for the creation of an enabling environment such as provision of tutorials and academic support services to students. On this, Soudien (2020) is instructive when she says that even though learning is often conceived of as an individual learning effort, it is also a social activity.

Thus, in the context of this article, the concept epistemic access and success refers to when students who come from disadvantaged backgrounds succeed academically against all odds. I argue that although providing access to higher education is a laudable idea, without the success of students, admitting students is a futile exercise. Thus, I argue that access should go beyond the quantitative to the quality of access given. Du Plooy and Zilindile (2014) have lamented these students' lack of success. I agree with Morrow's (2009) assertion that epistemological access is bounded by the past and present context in South African education. For example, it is important to acknowledge that epistemic access is shaped by historical, political and structural conditions surrounding the establishment of institutions of higher education. This understanding is important to the transformation agenda in South Africa (Ng'ethe, George, and George 2008).

\section{IMPLICATIONS}

I have deliberately avoided to use of the term recommendations for this section of the article. I am afraid to do so because the decolonisation of curricula is a complicated discourse. The thoughts I have expressed here are in no way a panpharmacon. The American experience of curriculum that adopted a movement or consortium approach (e.g., reconceptualists like Pinar 
1978, and his team) should teach us a lesson that this task cannot be undertaken by a single individual. It must be a project for a number of university teams of curriculum specialists and researchers. In Sepedi we call it "kgoro ya mošate" an assembly of wise elderly people. It exacts a concerted effort of dedicated individuals inclusive of all key stakeholders.

At individual universities, this task should not be left in the custody of one individual. It should be spread throughout all faculties, schools and departments so that it penetrates the soul and the heart of the entire institution. It should not be treated as an add on, but as part of the core business of the university. This is more or less what Schwab (1966) and his team did at Chicago University on Curriculum as the Practical or Paul Cobb (2007) and his team at the Vanderbilt University on the Mathematics Design Education Experience.

Although I advocate for a broader view of curriculum as better placed to deliver a decolonised curriculum, as opposed to the narrow view, I am in not abrogating the latter view. The curriculum project should avoid thinking in binary terms. For example, accessibility to higher education is a process that is fraught with absurdities, complications and contradictions. Surprisingly, this is often taken as natural or self-evident. Often what is perpetrated in the name of the narrow is sometimes an acknowledgement of the practice of exclusion.

I have not provided solutions, because that was not my intention. I merely wanted to provoke debates on this complicated discourse. Let us continue to engage and deliberate about drivers and inhibitors of diversity and social justice in South African higher education until we can come up with a decolonised curriculum for the good of our students and the country.

\section{REFERENCES}

Badat, Saleem. 2010. "The challenges of transformation in higher education and training institutions in South Africa." Development Bank of Southern Africa 8(1): 1-37.

Badat, Saleem. 2014. South African higher education in the 20th year of democracy: Context, achievements and key challenges. Grahamstown: Rhodes University.

Begum, Neema and S. Rima. 2019. "Decolonising the curriculum.” Political Studies Review 17(2): 196201.

Bernstein, Basil. 1971. Class codes and control Volume 3. Routledge and Kegan Paul London: UK Press.

Bhambra, Gurminder K., G. Dalia, and N. Kerem. (Eds.). 2018. "Introduction: Decolonising the university." In Decolonising the university, 1-18. Birmingham: Pluto Press.

Blackie, Margaret, Le Roux, and McKenna. 2016. "Possible futures for science and engineering education." Higher Education (71): 755-766.

Chilisa, Bagele. 2017. "Decolonising transdisciplinary research approaches: An African perspective for enhancing knowledge integration in sustainability science." Sustainability Science 12(5): 813827.

Cobb, Paul. 2007. "Putting philosophy to work." In Second handbook of research on mathematics teaching and learning: A project of the National Council of Teachers of Mathematics 1(1). USA: Charlotte, N.C.: Information Age Pub. 
Cornbleth, Catherine. 1997. "On the wings of dreams: Response to Edward A. Wynne's review of the Great Speckled Bird.” Curriculum Inquiry 27(1): 113-120.

Cross, Michael, and Vivian Atinde. 2015. "The pedagogy of the marginalized: Understanding how historically disadvantaged students negotiate their epistemic access in a diverse university environment." Review of Education, Pedagogy, and Cultural Studies 37(4): 308-325.

Darling-Hammond, Linda, Lisa Flook, Channa Cook-Harvey, Brigid Barron, and David Osher. 2020. "Implications for educational practice of the science of learning and development." Applied Developmental Science 24(2): 97-140.

Deleuze, Gilles, and Félix Guattari. 1984. Anti-Oedipus: Capitalism and schizophrenia. Translated by Robert Hurley, Mike Seem and Helen R. Lane. London: Athlone.

Department of Education. 1997. Education White Paper 3: A programme for the transformation of higher education. Pretoria: Government Gazette 386, no. 18207.

Department of Higher Education and Training. 2001. National Plan on Higher Education. Pretoria: DHET.

Department of Higher Education and Training. 2014. The Policy Framework on differentiation in the South African Post-School system. Pretoria: DHET.

DHET see Department of Higher Education and Training.

DoE see Department of Education.

Du Plooy, Lucinda, and Mphumzi Zilindile. 2014. "Problematising the concept epistemological access with regard to foundation phase education towards quality schooling." South African Journal of Childhood Education 4(1): 187-201.

Essop, Ahmed. 2020. The changing size and shape of the higher education system in South Africa 20052017. Johannesburg: Ali Mazrui Centre for Higher Education Studies.

Hoadley, Ursula, and Jonathan D. Jansen. 2009. Curriculum: Organizing knowledge for the classroom. Cape Town: Oxford University Press Southern Africa.

Jansen, Jonathan D. 1999. "Globalisation, curriculum and the Third World State: In dialogue with Michael Apple." Current Issues in Comparative Education 1(2): 42-47.

Jansen, Jonathan D. 2017. "The lost scholarship of changing curricula." South African Journal of Science 113(6): 1-2.

Johnson, Bonnie. J. 2020. "Community engagement: Barriers and drivers in South African higher education." South African Journal of Higher Education 34(6): 87-105.

Keet, André. 2014. "Epistemic 'othering' and the decolonisation of knowledge." Africa Insight 44(1): $23-37$.

Kraak, André. (Ed.). 2000. Changing modes: New knowledge production and its implications for higher education in South Africa. Pretoria: HSRC Press.

Luckett, Kathy. 2009. "The relationship between knowledge structure and curriculum: A case study in sociology." Studies in Higher Education 34(4): 441-453.

Makalela, Leketi. 2015. "Translanguaging practices in complex multilingual spaces: A discontinuous continuity in post-independent South Africa." International Journal of the Sociology of Language (234): 115-132.

Mashiyi, N. F., L. Meda, and A. Swart. 2020. "Lecturer conceptions of and approaches to decolonisation of curricula in higher education." South African Journal of Higher Education 34(2): 146-163.

Mbembe, Joseph, A. 2016. "Decolonising the university: New Directions." Arts and Humanities in Higher Education 15(1): 29-45. https://doi.org/10.1177/1474022215618513.

Morrow, Wally. 2009. Bounds of democracy: Epistemological access in higher education. Pretoria: HSRC Press. https://www.hsrcpress.ac.za/books/bounds-of-democracy.

Muller, Johan. 2006. "Differentiation and progression in the curriculum." In Knowledge, curriculum and qualifications for South African further education, edited by Education, Science and Skills 
Development Research Programme for HSRC, Pretoria, 66-86. Pretoria: HSRC.

Muller, Johan. 2009. "Forms of knowledge and curriculum coherence." Journal of Education and Work 22(3): 205-226.

Ndlovu-Gatsheni, Sabelo J. 2015. "Decoloniality as the future of Africa." History Compass 13(10): 485-496.

Ng'ethe, Njuguna, S. George and A. George. 2008. Differentiation and articulation in tertiary education systems: A study of twelve African countries. No. 145. World Bank Publications.

Osher, David, K. Pittman, J. Young, H. Smith, D. Moroney and M. Irby. 2020a. Thriving, robust equity, and transformative learning and development: A more powerful conceptualization of the contributors to youth success. Washington, DC: American Institutes for Research and Forum for Youth Investment.

Osher, David, Pamela Cantor, Juliette Berg, Lily Steyer, and Todd Rose. 2020b. "Drivers of human development: How relationships and context shape learning and development." Applied Developmental Science 24(1): 6-36.

Pinar, William F. 1978. "The reconceptualisation of curriculum studies." Journal of Curriculum Studies 10(3): 205-214.

Saltmarsh, John, and M. Hartley. (Eds.). 2011. "To serve a larger purpose: Engagement for democracy and the transformation of higher education." Journal of Public Scholarship in Higher Education (2): $1-5$.

Schwab, Joseph J. 1966. "The practical: A language for curriculum.” The School Review 78(1): 1-23.

Singh, Mala. 2001. "Reinserting the "public good" into higher education transformation." Kagisano Higher Education Discussion Series 1: 8-18.

Singh, Mala. 2011. "The place of social justice in higher education and social change discourses." Compare: A Journal of Comparative and International Education 41(4): 481-494.

Soudien, Crain. 2020. "Systemic shock: How Covid-19 exposes our learning challenges in education." Southern African Review of Education 26(1): 6-19.

Swartz, R., M. Ivancheva, L. Czerniewicz, and N. P. Morris. 2019. "Between a rock and a hard place: Dilemmas regarding the purpose of public universities in South Africa." Higher Education 77: 567-583. doi:10.1007/s10734-018-0291-9.

Themane, Mahlapahlapana. 2011. "Understanding curriculum: A challenge to curriculum development in teacher education programmes." South African Journal of Higher Education 25(8): 1639-1651.

Throw, Martin. 2007. "Reflections on the transition from elite to mass to universal access: Forms and phases of higher education in modern societies since WWII." In International handbook of higher education, 243-280. Springer, Dordrecht.

Wyse, Dominic, Louise Hayward, Kay Livingston, and Steve Higgins. 2014. "Creating curricula: Aims, knowledge, and control." A special edition of the Curriculum Journal 2014: 2-6.

Young, Michael. 2014. "What is a curriculum and what can it do?" Curriculum Journal 25(1): 7-13. 